\title{
Applications of New Validated RP-HPLC Method for Determination of Indomethacin and its Hydrolytic Degradants using Sodium Acetate Buffer
}

\author{
Sanjay Pai and Neelam Sawant \\ Department of Quality Assurance, Goa College of Pharmacy,18 ${ }^{\text {th }}$ June Road, Panaji, Goa - 403001 , INDIA.
}

\begin{abstract}
Objective: A New RP-HPLC method for estimation of indomethacin and its two degradant impurities 4-chlorobenzoic acid, 5-methoxy-2-methyl-indoleacetic acid was developed and validated as per $\mathrm{ICH}$ guidelines. Background: This new method is not only capable of identifying and quantifying the impurities but also can be used for the assay of indomethacin in marketed capsule formulations. Methods: The chromatographic conditions were optimized using Zorbax Eclipse Plus C18, $3.5 \mu \mathrm{m}(4.6 \mathrm{~mm} \times 100 \mathrm{~mm})$ column with methanol: acetonitrile: $10 \mathrm{mM}$ sodium acetate buffer $\mathrm{pH} 3,10: 50: 40 \% \mathrm{v} / \mathrm{v}$ as the mobile phase at the flow rate of $1 \mathrm{ml} / \mathrm{min}$ and detection was carried out using UV-Visible PDA detector at $254 \mathrm{~nm}$. Results: The method was linear over concentration range of $25-70 \mu \mathrm{g} / \mathrm{ml}$ for indomethacin, $0.25-2 \mu \mathrm{g} / \mathrm{ml}$ for 4-chlorobenzoic acid and 0.25$2 \mu \mathrm{g} / \mathrm{ml}$ for 5-methoxy-2-methyl-indoleacetic acid. The developed method was validated as per the $\mathrm{ICH}$ guidelines for linearity, accuracy, precision, limit of detection, limit of quantification, robustness and specificity for indomethacin and its impurities.
\end{abstract}

Key Words: RP-HPLC, Indomethacin, 4-chlorobenzoic acid, 5-methoxy-2-methylindoleacetic acid, Validation.

\section{INTRODUCTION}

Indomethacin belongs to the class of heteroarylacetic acid derivatives of NSAIDs and is used for the treatment of acute gouty arthritis, acute pain of ankylosing spondylitis and osteoarthritis. The anti-inflammatory, antipyretic and analgesic actions of indomethacin are due to the ability to inhibit prostaglandin biosynthesis. ${ }^{1}$ The drug is official in Indian Pharmacopoeia, ${ }^{2}$ British Pharmacopoeia ${ }^{3}$ and United States Pharmacopoeia. ${ }^{4}$ Chemically indomethacin is 1-(4-chlorobenzoyl)-5-methoxy-2-methylindol-3-ylacetic acid (Figure 1). The estimation of indomethacin in capsules has been done by UV spectrophotometry,-9 Colorimetric methods, ${ }^{10-11}$ and RP-HPLC $^{12-13}$ methods. British Pharmacopoeia 2013 specifies 4-chlorobenzoic acid as an impurity of Indomethacin. Along with 4-chlorobenzoic acid (Figure 2), 5-methoxy-2-methyl-indole- acetic acid (Figure 3) has been identified as another impurity by Tsvetkova B et al, ${ }^{14}$ Novakova L et al,,$^{15}$ Kwong E et al, ${ }^{16}$ Sonja $\mathrm{H}$ et $a l^{17}$, Krzek J et $a l^{18}$ and Karima Fadhil Ali et $a l^{19}$ and analyzed by RP-HPLC methods, UV spectrophotometric methods and Densitometric method in literature. Both these impurities are the degradation products of Indomethacin under hydrolytic conditions. The reported methods have a longer analysis time ranging from 5 to $10 \mathrm{~min}$. The objective of the study was to develop newer RP-HPLC method for identification and analysis of indomethacin in presence of two possible degradant impurities 4-chlorobenzoic acid and 5-methoxy-2-methyl-indoleacetic acid in pharmaceutical capsule dosage formulation with emphasis on shortening the analysis time and validate in accordance with the ICH guidelines. ${ }^{20}$
Submission Date: 19-08-2016; Revision Date: 17-11-2016; Accepted Date: 15-02-2017

DOI: 10.5530/ijper.51.3.65 Correspondence: Sanjay Pai P.N, Department of Quality Assurance, Goa College of Pharmacy, 18th June Road, Panaji, Goa - 403 001, INDIA.

Phone: +91-832-2226882 E-mail: pnsanjaypai@gmail. com

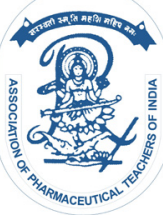

www.ijper.org 


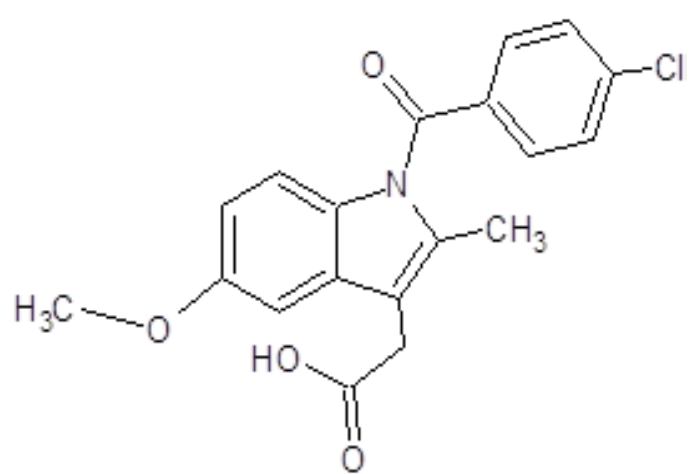

Figure 1: Structure of Indomethacin<smiles>O=C(O)c1ccc(Cl)cc1</smiles>

Figure 2: Structure of 4-Chlorobenzoic acid

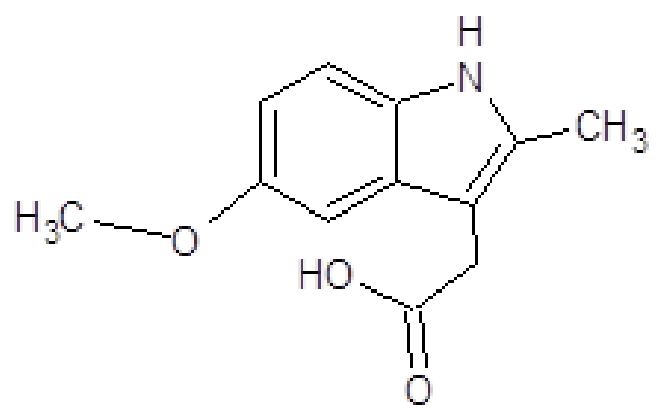

Figure 3: Structure of 5-Methoxy-2-methyl indoleacetic acid

\section{MATERIAL AND METHODS}

\section{Equipment}

The studies were performed on two HPLC - Agilent 1260 and JASCO, Japan both equipped with autosampler and auto injector with PDA detector and Double beam UV/VIS spectrophotometer of Lab India ${ }^{\circledR}$ make of UV $3000^{+}$Analytical Tech model. The reference standard of Indomethacin was supplied by Jagsonpal Pharmaceuticals Ltd., whereas, 4-chlorobenzoic acid and 5-methoxy-2-methylindoleacetic acid were purchased from Aldrich Chemicals. Indocap ${ }^{\circledR}$ containing $25 \mathrm{mg}$ of indomethacin per capsule was purchased from the local market. HPLC grade methanol, acetonitrile and water was purchased from Merck Specialities Private Limited, Mumbai. Sodium acetate and glacial acetic acid (AR grade) was obtained from Loba Chemie Pvt. Ltd. and Thomas Baker, Mumbai respectively.

\section{Chromatographic conditions}

HPLC analyses for method development and validation was performed on Zorbax Eclipse Plus C-18, $3.5 \mu \mathrm{m}$ $(4.6 \mathrm{~mm} \times 100 \mathrm{~mm})$ column was used for the separation. Isocratic system of Methanol: acetonitrile: $10 \mathrm{mM}$ sodium acetate buffer $\mathrm{pH} 3,10: 50: 40 \% \mathrm{v} / \mathrm{v}$ was delivered at a flow rate of $1 \mathrm{ml} / \mathrm{min}$ and detection carried out at $254 \mathrm{~nm}$. The injection volume was $5 \mu \mathrm{l}$ and the analysis was performed at ambient temperature.

\section{Preparation of Standard stock solutions}

Standard stock solutions of indomethacin and both the impurities were prepared by dissolving $10 \mathrm{mg}$ of each separately in $10 \mathrm{ml}$ of methanol in three separate 10 $\mathrm{ml}$ volumetric flasks to obtain concentration of 1000 $\mu \mathrm{g} / \mathrm{ml}$. Further dilutions were made with the mobile phase to obtain final concentrations of $10-100 \mu \mathrm{g} / \mathrm{ml}$ for indomethacin standard and $0.1-2.5 \mu \mathrm{g} / \mathrm{ml}$ for both the impurity working standard solutions respectively.

\section{Preparation of sample solution}

Quantity of mixed contents of 20 capsules containing about $10 \mathrm{mg}$ of indomethacin was weighed and transferred to $100 \mathrm{ml}$ volumetric flask. About $10 \mathrm{ml}$ of water was added and allowed to stand for $10 \mathrm{~min}$ with occasional stirring. $75 \mathrm{ml}$ of methanol was added and shaken well and sufficient methanol was added to make up the volume to $100 \mathrm{ml}$. The solution was filtered through $0.45 \mu \mathrm{m}$ filter to obtain sample stock solution. The sample stock solution was further diluted with mobile phase to obtain final concentration of $30 \mu \mathrm{g} / \mathrm{ml}$ for sample analysis of indomethacin.

\section{VALIDATION}

The method was validated for linearity, precision, specificity, accuracy, limit of detection, limit of quantification, ruggedness and robustness as per the $\mathrm{ICH}$ guidelines ${ }^{20}$. The linearity of calibration curves of indomethacin was determined over the concentration range of 25-70 $\mu \mathrm{g} / \mathrm{ml}$. For both the degradation products linearity was tested from $0.1-6.6 \%$ of the active substance indomethacin and was found to be linear in the concentration range of $0.25-2 \mu \mathrm{g} / \mathrm{ml}$. Accuracy was determined by spiking standard solutions in the previously analysed sample solutions at three different levels of i.e. $80 \%, 100 \%$ and $120 \%$ of the target concentration and calculating the $\%$ recovery. Precision was calculated on six replicate injections of the sample solution at two levels 0.25 and $2 \mu \mathrm{g} /$ $\mathrm{ml}$, being the lower and higher concentration of linear- 
ity range. Specificity study was carried out by comparing chromatograms of blank, standard solutions and sample solution spiked with both the impurities. The LOD and LOQ were calculated from the standard calibration curves based on standard deviation formula with equations $\mathrm{LOD}=3.3 \sigma / \mathrm{S}$ and $\mathrm{LOQ}=10 \sigma / \mathrm{S}$; where, $\sigma$ is the standard deviation of the response and $\mathrm{S}$ is the slope of the calibration curve. Robustness of the method was determined by making slight changes in the operating conditions viz. flow rate $\pm 0.2 \mathrm{ml}$, change in the organic phase ratio by $\pm 2 \% \mathrm{v} / \mathrm{v}$ and $\mathrm{pH}$ by \pm 0.2 units. System suitability was determined before sample analysis from six replicate injections. The solution stability was determined by performing the analysis up to $8 \mathrm{hr}$ with the working solutions.

\section{RESULTS AND DISCUSSION}

The aim of this RP-HPLC method was to estimate indomethacin and its two impurities in capsule formulation and validate it in accordance with the ICH guidelines. This method can also find an application in assay of indomethacin in its solid dosage form. As both the impurities are present in very low concentrations as compared to indomethacin there was a need to select the detection wavelength, where impurities showed significantly higher absorbance than the active substance; hence $254 \mathrm{~nm}$ was selected as the detection wavelength. UV overlain spectra of indomethacin and both impurities in the optimized mobile phase is shown in Figure 4. The chromatographic separation was achieved using Zorbax Eclipse Plus C-18, $3.5 \mu \mathrm{m}(4.6 \mathrm{~mm} \times 100 \mathrm{~mm})$ column. After performing exploratory trials methanol: acetonitrile: $10 \mathrm{mM}$ sodium acetate buffer $\mathrm{pH} 3$, 10:50:40\% v/v with flow rate of $1 \mathrm{ml} / \mathrm{min}$ was selected

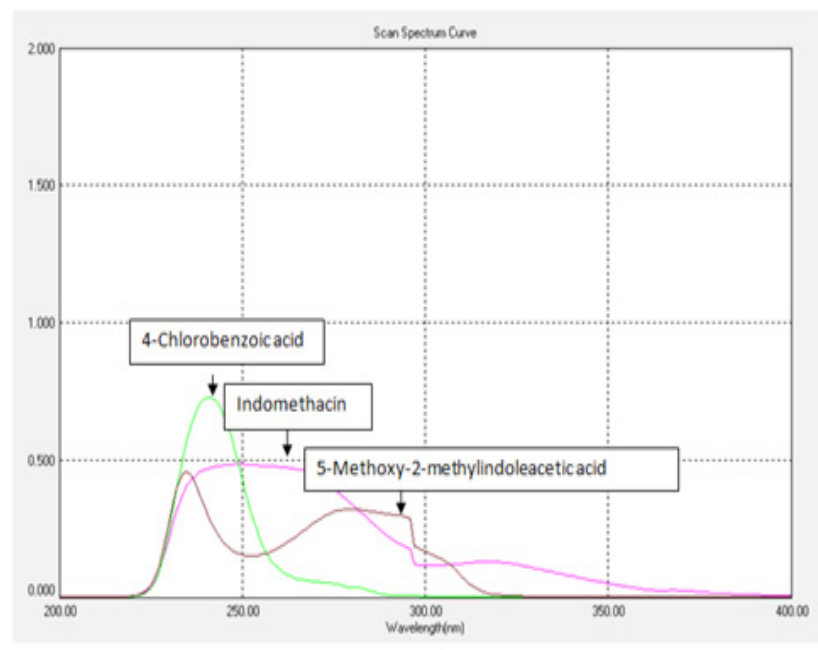

Figure 4: UV overlain spectra spectra of indomethacin, 4-chlorobenzoic acid and 5-methoxy-2-methyl-indoleacetic acid in the optimized mobile phase as the optimized mobile phase. The retention times of indomethacin, 4-chlorobenzoic acid and 5-methoxy2-methylindoleacetic acid were $3.767 \mathrm{~min}, 1.627 \mathrm{~min}$ and $1.240 \mathrm{~min}$ respectively. Resolution of the method was found to be highly satisfactory as indicated by good separation of compound peaks. The chromatogram of indomethacin sample solution spiked with the two impurities is shown in Figure 5. The system suitability tests were carried out and parameters are summarized in Table 1. The assay results for indomethacin capsules are shown in the Table 1 and \% RSD of assay was found to be within limit of $2 \%$. The linearity range for indomethacin was found to be $25-70 \mu \mathrm{g} / \mathrm{ml}$, for impurities 4-chlorobenzoic acid $0.25-2 \mu \mathrm{g} / \mathrm{ml}$ and 5-methoxy2 -methyl-indoleacetic $0.25-2 \mu \mathrm{g} / \mathrm{ml}$. The accuracy was determined by calculating \% recovery at 3 levels of 80,100 and $120 \%$ and was found to be well within the acceptable limits. RSD for repeatability and inter-day precision was found to be less than $2 \%$ which is within the acceptance limit and indicates that the method is precise. The detection limit and quantitaion limit of indomethacin, 4-chlorobenzoic acid and 5-methoxy-2 methyl-indole acetic acid was found to be $1.036 \mu \mathrm{g} / \mathrm{ml}$, $0.104 \mu \mathrm{g} / \mathrm{ml}, 0.104 \mu \mathrm{g} / \mathrm{ml}$ and $3.141 \mu \mathrm{g} / \mathrm{ml}, 0.308 \mu \mathrm{g} /$ $\mathrm{ml}, 0.308 \mu \mathrm{g} / \mathrm{ml}$ respectively. There was no other visible peak at retention time up to $10 \mathrm{~min}$ indicating high degree of specificity of the method. The method validation results are summarised in Table 1 . The robustness of the method was determined on the sample solution by slightly varying the mobile phase ratio, $\mathrm{pH}$, flow rate and the percent recovery was found to be within limits. It was observed that the retention time and peak area of all the working standard and sample solutions remained unchanged and no significant degradation observed up to $8 \mathrm{hr}$ at ambient temperature. Thus, the new method is found to be accurate, precise and specific and could be used for routine analysis of indomethacin in pres-

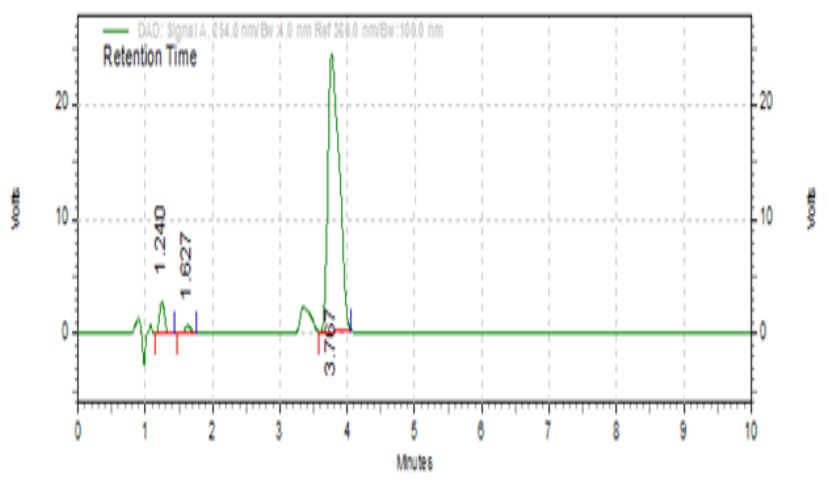

Figure 5: Chromatogram of Indomethacin spiked with 4-chlorobenzoic acid and 5-methoxy-2-methyl-indoleacetic acid in the optimized mobile phase 
Table 1: Method validation results

\begin{tabular}{l|l} 
Indomethacin & 4-Chlorobenzoic acid
\end{tabular}

5-methoxy-2-methyl-indoleacetic

acid

SYSTEM SUITABILITY TESTS

\begin{tabular}{|c|c|c|c|}
\hline Theoretical plates & 2457 & 1758 & 1672 \\
\hline Asymmetry & 1.26 & 0.00 & 1.25 \\
\hline Resolution & 9.69 & 2.90 & \\
\hline \multicolumn{2}{|c|}{ VALIDATION }
\end{tabular}

\begin{tabular}{|c|c|c|c|c|c|}
\hline Linearity $(\mu \mathrm{g} / \mathrm{ml})$ & $25-70 \mu \mathrm{g} / \mathrm{ml}$ & \multicolumn{2}{|c|}{$0.25-2 \mu \mathrm{g} / \mathrm{ml}$} & \multicolumn{2}{|c|}{$0.25-2 \mu \mathrm{g} / \mathrm{ml}$} \\
\hline Regression equation & $\begin{array}{c}y=1,630,399.06 x \\
-2,204,584.44\end{array}$ & \multicolumn{2}{|c|}{$y=385776 x+140995$} & \multicolumn{2}{|c|}{$y=739706 x+84634$} \\
\hline Correlation coefficient ( $R^{2}$ value) & 0.9992 & \multicolumn{2}{|c|}{0.9985} & \multicolumn{2}{|c|}{0.999} \\
\hline \multicolumn{6}{|l|}{ Accuracy (\%) } \\
\hline $80 \%$ & $99.70 \%$ & \multicolumn{2}{|c|}{$100.31 \%$} & \multicolumn{2}{|c|}{$101.6 \%$} \\
\hline $100 \%$ & $100.06 \%$ & \multicolumn{2}{|c|}{$100.49 \%$} & \multicolumn{2}{|c|}{$101.4 \%$} \\
\hline $120 \%$ & $99.28 \%$ & \multicolumn{2}{|c|}{$101.18 \%$} & \multicolumn{2}{|c|}{$99.63 \%$} \\
\hline Precision $(n=6)$ & $30 \mu \mathrm{g} / \mathrm{ml}$ & $0.25 \mu \mathrm{g} / \mathrm{ml}$ & $2 \mu \mathrm{g} / \mathrm{ml}$ & $0.25 \mu \mathrm{g} / \mathrm{ml}$ & $2 \mu \mathrm{g} / \mathrm{m}$ \\
\hline Repeatability (\% RSD) & 0.003 & 1.624 & 0.449 & 1.708 & 0.448 \\
\hline Intermediate Precision (\% RSD) & 0.005 & 1.860 & 0.336 & 1.651 & 0.480 \\
\hline Limit of Detection $(\mu \mathrm{g} / \mathrm{ml})$ & $1.036 \mu \mathrm{g} / \mathrm{ml}$ & \multicolumn{2}{|c|}{$0.104 \mu \mathrm{g} / \mathrm{ml}$} & \multicolumn{2}{|c|}{$0.104 \mu \mathrm{g} / \mathrm{ml}$} \\
\hline Limit of Quantitation $(\mu \mathrm{g} / \mathrm{ml})$ & $3.141 \mu \mathrm{g} / \mathrm{ml}$ & \multicolumn{2}{|c|}{$0.308 \mu \mathrm{g} / \mathrm{ml}$} & \multicolumn{2}{|c|}{$0.308 \mu \mathrm{g} / \mathrm{ml}$} \\
\hline Assay (\%) & $98.60 \%$ & \multicolumn{2}{|c|}{ - } & \multicolumn{2}{|c|}{-} \\
\hline Retention time (min) & 3.767 & \multicolumn{2}{|c|}{1.627} & \multicolumn{2}{|c|}{1.240} \\
\hline
\end{tabular}

ence of its hydrolytic impurities 4-chlorobenzoic acid and 5-methoxy-2-methyl-indoleacetic acid.

\section{CONCLUSION}

A new RP-HPLC method was developed and validated for estimation of indomethacin and its two impurities using methanol, acetonitrile and a volatile buffer. All the compounds eluted within $5 \mathrm{~min}$ and thus required shorter time of analysis. The method is simple, accurate, precise and robust and can be used for routine analysis of indomethacin in its marketed formulation.

\section{ACKNOWLEDGEMENT}

The authors sincerely thank Jagsonpal Pharmaceuticals Ltd., Baddi, Himachal Pradesh for providing the gift sample of Indomethacin.

\section{REFERENCES}

1. Borne R, Levi M, Wilson N. Nonsteroidal anti-inflammatory drugs. In: Lemke TL, editor. Foye's principles of Medicinal Chemistry, 6th ed. China: Lippincott Williams and Wilkins. 2008;970-1.

2. Indian Pharmacopoeia. The Indian Pharmacopoeia Commission. Ghaziabad: Govt. of India Ministry of Health and Family Welfare. 2014;2:1960-1.

3. British pharmacopoeia. The Stationery Office on behalf of the Medicines and Healthcare products Regulatory Agency (MHRA). Great Britain: The Department of Health. 2013;1:1154-5.
4. United States Pharmacopoeia. Rockville: United States Pharmacopoeial Convention, Inc; 2013;2;3902-3.

5. Maheshwari RK, Dahima R. "Solid as solvent"- Novel spectrophotometric analysis of indomethacin capsules using melted phenol as solvent. Der Pharma Chemica. 2015(1);7:112-5.

6. Ali KF, Albakaa RM, Ali ZH. New assay method UV spectroscopy for determination of Indomethacin in pharmaceutical formulation. Journal of Chemical and Pharmaceutical Research. 2015;7:1591-6.

7. Maheshwari RK, Rathore A, Agrawal A, and Gupta MA. New spectrophotometric estimation of indomethacin capsules with niacinamide as hydrotropic solubilizing agent. Pharm Methods. 2011;2(3):184-8. https://doi. org/10.4103/2229-4708.90359 ; PMid:23781453 PMCid:PMC3658053.

8. Aman T, Naureen F, Kazi AA, Khan IU and Kashmiri MA. Ammonium Molybdate as a Spectrophotometric Reagent for the determination of indomethacin in pure and pharamaceutical preparations. Analytical Letters - ANAL LETT. 2002;35(6):1007-20. https://doi.org/10.1081/AL-120004552.

9. Nagaraja P, Vasantha RA, Yathirajan HS. Sensitive spectrophotometric method for the determination of indomethacin in capsules. Journal of Pharmaceutical and Biomedical Analysis. 2003;31(3):563-9. https://doi. org/10.1016/S0731-7085(02)00465-X.

10. Adegoke OA, Idowu OS, Olaniyi AA. Novel colorimetric assay of indomethacin using 4-carboxyl-2,6-dinitrobenzene diazonium ion. Acta Pharm. 2006;56(2):189-202. PMid:16613725.

11. Abdel-hay $\mathrm{MH}$, Korany MA, Bedair MM and Gazy AA. Colorimetric Determination of Seven Nonsteroidal Antiinflammatory Drugs Using 2-Nitrophenylhydrazine Hydrochloride. Analytical Letters. 1990;23(2):28194. https://doi.org/10.1080/00032719008052444.

12. Plakogiannis FM, Ali A and Kazmi S. High-Pressure Liquid Chromatographic Determination of Indomethacin in Capsules. Drug Development and Industrial Pharmacy. 1981;7:215-21. https://doi.org/10.3109/03639048109057712.

13. Zhang D, Zeng J, Bianba C, Jiang X. Determination of plasma drug concentration and bioavailability of indomethacin controlled release capsule by high performance liquid chromatography. Se Pu. 1997;15(6):515-7.; PMid:15739336. 
14. Tsvetkova B, Pencheva I, Zlatkov A, Peikov P. High performance liquid chromatographic assay of Hndomethacin and its related substances in tablet dosage forms. International Journal of Pharmacy and Pharmaceutical Sciences. 2012;4:549-52.

15. Novakov L, Matysov L, Havlıkova L, Solich P. Development and validation of HPLC method for determination of indomethacin and its two degradation products in topical gel. Journal of Pharmaceutical and Biomedical Analysis. 2005;37(5):899-905. https://doi.org/10.1016/j.jpba.2004.09.012; PMid:15862664.

16. Kwong E, Pillai GK, McErlane KM. HPLC analysis of indomethacin and its impurities in capsule and suppository formulations. Journal of Pharmaceutical Sciences. 1982;71(7):828-30. https://doi.org/10.1002/jps.2600710730 ; PMid:7120076.

17. Hess S, Teubert U, Ortwein J, Eger K. Profiling indomethacin impurities using high-performance liquid chromatography and nuclear magnetic resonance.

PICTORIAL ABSTRACT

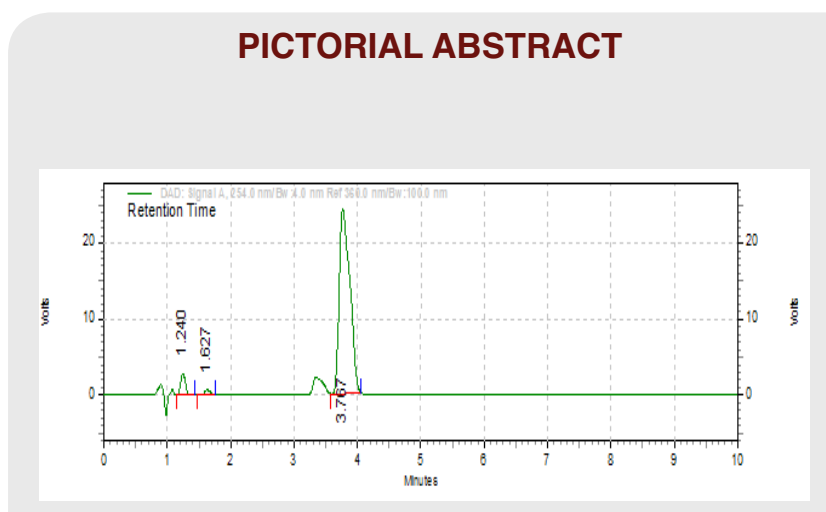

European Journal of Pharmaceutical Sciences. 2001;14(4):301-11. https:// doi.org/10.1016/S0928-0987(01)00198-1.

18. Krzek J, Starek, Magorzata. Simultaneous Densitometric Determination of Indomethacin and Its Degradation Products, 4-Chlorobenzoic Acid and 5-Methoxy-2-Methyl-3-Indoleacetic Acid, in Pharmaceutical Preparations. Journal of AOAC International. 2001;84(6):1703-7. PMid:11767134.

19. Ali KF, Albakaa ARM and Ali ZH. New assay method UV spectroscopy for determination of Indomethacin in pharmaceutical formulation. Journal of Chemical and Pharmaceutical Research. 2015;7:1591-6.

20. Guidance for industry, Q2 (R1) Validation of Analytical Procedures: Methodology, U.S. Department of Health and Human Services, Food and drug administration, Centre for Drug evaluation and Research (CDER), centre for Biologics Evaluation and Research (CBER), International Conference on Harmonization, Geneva, November 2005.

\section{SUMMARY}

- Indomethacin degradants 4-chlorobenzoic acid and 5-methoxy-2-methyl indoleaceticacid are reported as hydrolytic impurities.

- New validated RP-HPLC method is developed on an ODS column to identify Indomethacin and its two hydrolytic degradants within short run time of $5 \mathrm{~min}$.

- The new method can be successfully applied for analysis of Indomethacin in marketed capsule dosage forms and for impurity profiling experiments
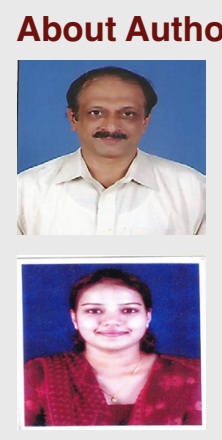

Sanjay Pai: Academic researcher, with research interests in impurity profiling of drugs, new molecule synthesis, stability studies of drug substances and analytical method development.

Neelam Sawant: Academic researcher, with research interests in Pharmaceutical Quality Assurance and Documentation, stability studies of drug substances and analytical method development.

Cite this article: Pai S, Sawant N. Applications of New Validated RP-HPLC Method for Determination of Indomethacin and its Hydrolytic Degradants using Sodium Acetate Buffer. Indian J of Pharmaceutical Education and Research. 2017;51(3):388-92. 